University of New England

DUNE: DigitalUNE

$6-2020$

Mixed Consequences Of Divorce On Reproductive Success Of

Songbirds Nesting In Agricultural Hayfields

Kylee DiMaggio

Noah G. Perlut

Allan Strong

Follow this and additional works at: https://dune.une.edu/env_facpubs

Part of the Ornithology Commons 


\title{
Mixed consequences of divorce on reproductive success of songbirds nesting in agricultural hayfields
}

\author{
Kylee DiMaggio, ${ }^{1}$ Noah Perlut, ${ }^{1 *}$ and Allan Strong ${ }^{2}$
}

\begin{abstract}
Agricultural management, particularly haying, can cause synchronous nest failure of ground-nesting songbirds. As a consequence, these birds may subsequently renest and choose a new social mate (divorce). This study (1) quantified within-year and between-year divorce rates of grassland songbirds, and (2) determined if divorce rates differed after haying or predation-caused nest failure, and if so, whether divorce influenced reproductive success. From 2002 to 2017 , we monitored 121 Bobolink (Dolichonyx oryzivorus) pairs and 436 Savannah Sparrow (Passerculus sandwichensis) pairs in an agricultural region of Vermont, USA. Within-year and between-year divorce rates were $0-84.9 \%$ for Bobolinks and $17-$ $69.1 \%$ for Savannah Sparrows. Between years, Bobolinks, but not Savannah Sparrows, were more likely to divorce after nest failure, but haying did not influence divorce rates. Within years, Savannah Sparrows were more likely to divorce after nest failure, but as with Bobolinks, divorce rates in Savannah Sparrows were not different between nests that failed due to haying or predation. Across all Savannah Sparrow renests, divorce had no influence on the number of young fledged per female. However, between years, female Bobolinks that divorced fledged more young in their first attempt while those that did not divorce fledged more young in their second attempt. This study showed that pairing decisions were not differentially affected by cause of nest failure. Further, we identified no reproductive benefit to divorce. Our results indicate no adaptive benefit and potentially a significant reproductive cost to divorce, and that these effects vary between species. Received 22 January 2019. Accepted 20 October 2020.
\end{abstract}

Key words: agricultural management, Bobolink, grassland songbird, haying, mate choice, Savannah Sparrow.

\section{Consecuencias mixtas en el éxito reproductivo de pájaros que anidan en campos para el cultivo de forrajes}

RESUMEN (Spanish)_El manejo agrícola, particularmente el cultivo de forrajes, puede causar pérdidas sincrónicas en pájaros que anidan en el suelo. Como consecuencia, estas aves pueden reanidar subsecuentemente y elegir una nueva pareja social (divorcio). Este estudio 1) cuantificó las tasas de divorcio intra- e interanuales de pájaros de pastizales y 2) determinó si las tasas de divorcio difirieron después de la siega de forrajes o fallos en el nido ocasionados por depredadores, y de ser así, discernir si el divorcio influyó en el éxito reproductivo. De 20022017 monitoreamos 121 parejas del arrocero Dolichonyx oryzivorus y 436 parejas del gorrión Passerculus sandwichensis en una región agrícola de Vermont, Estados Unidos. Las tasas de divorcio intra- e interanuales fueron 0-84.9\% para el arrocero y 17-69.1\% para el gorrión, respectivamente. Entre años, los arroceros, mas no los gorriones, fueron más proclives a divorciarse después del fallo del nido, si bien la siega no influyó en la tasa de divorcios. Intraanualmente, los gorriones fueron más proclives a divorciarse después del fallo del nido, si bien como en el caso de los arroceros sus tasas de divorcio no difieren entre nidos fallidos por la siega o la depredación. Entre todas las reanidaciones del gorrión, el divorcio no tuvo influencia en el número de polluelos emancipados por hembra. Sin embargo, de manera interanual las hembras de arrocero que se divorciaron emanciparon más polluelos en su primer intento mientras que aquellas que no se divorciaron emanciparon más polluelos en su segundo intento. Este estudio muestra que las decisiones para formar parejas no fueron diferencialmente afectadas según las causas que ocasionaron el fallo de los nidos. Más aún, no identificamos ningún beneficio reproductivo del divorcio. Nuestros resultados indican que no hay un beneficio adaptativo o un costo potencialmente significativo por divorciarse y que sus efectos varían entre especies.

Palabras clave: Dolichonyx oryzivorus, elección de pareja, manejo agrícola, manejo cultural, pájaros de pastizal, Passerculus sandwichensis, siega.

The decision to divorce-select a different social mate in a subsequent nest attempt while the original mate is available to pair with-may significantly influence lifetime fitness (Culina et al. 2015, Crino et al. 2016). Divorce may also be a product of constrictions to initial mate choice, where an individual could not pair with a preferred mate because it was already paired. A metaanalysis of divorce and reproductive success in socially monogamous birds found that divorce (1)

${ }^{1}$ Department of Environmental Studies, University of New England, Biddeford, ME, USA

${ }^{2}$ Rubenstein School of Environment and Natural Resources, University of Vermont, Burlington, VT, USA

* Corresponding author: nperlut@une.edu is prompted by low success of previous breeding attempts, and (2) can have a positive influence on subsequent breeding success (Culina et al. 2015). Therefore, divorce may be an adaptive response to low reproductive success.

While divorce can be an adaptive strategy, the causes and consequences of divorce are diverse. Females can improve their breeding success (Wheelwright and Teplitsky 2017) and produce more genetically diverse offspring in unpredictable environments (Botero and Rubenstein 2012), and divorce may allow migratory birds to avoid the disadvantage of spending time searching (and waiting) for previous mates (Choudhury 1995). More prominently, divorce is also positively 
correlated with increased brood size between breeding seasons, allowing divorced birds to advance the time of breeding and increase the number of young fledged more so than those that re-paired with a previous mate (Culina et al. 2015). However, there are also benefits to mate fidelity. For example, re-pairing can increase clutch mass, which can be positively correlated with hatchling growth rates (Crino et al. 2016). Further potential benefits to re-pairing include lower susceptibility to predators and less competition in territory establishment (Choudhury 1995). Overall, fidelity may allow a pair to improve coordination and performance through familiarity.

While these studies provide insight into the variable nature of divorce in birds, to our knowledge, little is known about how habitat management affects the decision to divorce or repair. Understanding the effects of habitat management on social interactions - and the resulting fitness consequence(s) - is critically important in understanding population processes, as the majority of global terrestrial landscapes are managed (Hannah et al. 1995). Agricultural hay-harvesting causes nest destruction in ground-nesting, grassland songbirds; however, the timing of haying varies across agricultural landscapes (Perlut et al. 2008a, 2008b), providing an opportunity to look at neighboring populations with different management treatments. As a result, grassland songbirds nesting in agricultural landscapes may provide a model for understanding how habitat management affects the decisions birds make on mate selection and the associated fitness that comes with these decisions. For example, agricultural haying increased divorce rates and site dispersal in Whinchat (Saxicola rubetra). In this case, post-harvest, reproductive success decreased, attributed to increased within-season dispersal and subsequently lower renesting rates (Grüebler et al. 2015).

Our objective was to identify the frequency, and costs and benefits, of divorce on reproductive success in 2 species of grassland-nesting songbirds breeding in agricultural haylands. To address this objective, we tested 2 main hypotheses. The first hypothesis broadly explored the adaptive function of divorce: $\left(\mathrm{H}_{1}\right)$ divorce will increase the number of young fledged both within and between seasons (Beguin et al. 2006). The second hypothesis explored if an adaptive function operates within human-managed ecosystems: $\left(\mathrm{H}_{2}\right)$ on hayed fields, synchronous nest failure will constrain pairs to social monogamy post-harvest (Perlut et al. 2008a), therefore, divorce rates following haying will be lower than divorce rates following nest failure due to predation (which is asynchronous). Testing these hypotheses is essential to our understanding of how habitat management may affect the social structures and reproductive success of birds.

\section{Methods}

\section{Study site}

We monitored study sites in Shelburne and Hinesburg, Vermont, USA, from 2002 to 2017. This area is centrally situated in the Champlain Valley $\left(44^{\circ} 31^{\prime} 50.11^{\prime \prime} \mathrm{N}, 73^{\circ} 18^{\prime} 59.06^{\prime \prime} \mathrm{W}\right.$, elevation $28 \mathrm{~m}$ ), which includes $>150,000$ ha of managed grassland (Perlut et al. 2008b). We found and monitored nests of the ground-nesting, grasslandobligate Bobolink (Dolichonyx oryzivorus) and Savannah Sparrow (Passerculus sandwichensis). These species comprised $92 \%$ of the grasslandobligate songbirds breeding in our study region (Shustack 2004). Bobolinks are long-distance migrants that winter in Argentina and arrive at their Vermont breeding grounds in mid-May; Bobolinks are generally a single-brooded species (Renfrew et al. 2013, 2015). Savannah Sparrows are short-distance migrants that winter in the southern United States or Mexico and arrive at their Vermont breeding grounds in mid- to late April (Wheelwright and Rising 2008). Savannah Sparrows are generally a double-brooded species, and females commonly renest post-harvest, laying up to 6 clutches in a season (Perlut et al. 2006). Furthermore, pairs tend to be more socially and genetically monogamous post-harvest (Perlut et al. 2008a).

Our study fields were in 4 treatment types: early-hayed fields ("early") were cut between 16 May and 11 June and generally again in early to mid-July ( $n=6$ fields), middle-hayed fields ("middle") were hayed after 21 June $(n=4$ fields), late-hayed fields ("late") were cut after 1 August ( $n=13$ fields), typically after most birds have ended their reproductive season, and rotationally grazed pastures $(n=6$ fields; see Perlut et al. 2006 for additional details on field management). These fields are representative of the majority of the Champlain Valley's hayfield 
habitat, as $23 \%$ is harvested early and $45 \%$ harvested late (Perlut et al. 2008a). Each year on these plots, we captured and banded $>95 \%$ of the breeding birds. In late May we used $\sim 30$ mist nets to blanket net each field for 1-2 d. Each bird received a US Geological Survey numbered band as well as 3 colored bands. We searched for nests every $1-2 \mathrm{~d}$ on each field and maintained resight records of each banded bird we saw. We found nests through behavioral observation of females and determined female nest association by incubation or chick feeding. We determined male nest association through territory defense and chick feeding. If an adult associated with a nest was unbanded, we caught it near the nest location and banded it. We monitored each nest every 1-2 d until it either fledged or failed.

\section{Statistical analyses}

Following Culina et al. (2015), we defined divorce as having occurred when 2 previously paired individuals are alive and on the same field during the current (within-year) or next (betweenyear) breeding season and at least one of them has remated with a new partner. We pooled all nests across years for all analyses; furthermore, unless noted, we pooled nests across hayfield treatment types. We quantified the within-year and betweenyear divorce rates for both species across all years; we also assessed divorce rates across all nests (this sample pools both within-year and between-year analyses). By comparing the number fledged per female between nest attempts, we were also able to compare the reproductive success of divorced and non-divorced birds both within-year and betweenyear. To perform these analyses for both species we defined baselines for within-year and betweenyear analyses. Baselines for within-year analysis defined non-divorced individuals as members of a pair, both present at the same field location and committed to re-pairing with a previous mate. The within-year baseline for non-divorced individuals is further defined as individuals that have multiple nest attempts within the breeding season. Comparably, baselines for between-year, non-divorced individuals have the same conditions as withinyear baselines but instead compare only those individuals that are present on any of the study sites over multiple years.
We then compared the rate of divorce after initial failure by predation and haying. Here, we categorized nest attempts ending in divorce and non-divorce by their cause of failure, in an effort to examine whether cause of failure (e.g., haying) had a differential impact on frequency of divorce in these species. We performed this analysis for both within-year and between-year divorce.

We performed chi-square tests to analyze whether divorce rates differed between successful and failed nests, and to test the effect of cause of nest failure (depredation, haying; SAS Institute, Cary, North Carolina, USA). While there were additional causes of nest failure, they were too infrequent to include in the analysis (abandonment, trampling by cows, accidental research impact, weather, infertility). We used $t$-tests to compare number of young fledged pre- and postdivorce. We used general linear models (PROC GLM) to test if divorce rates differed with the number of young fledged per nest; year was included as a random effect in this model. We report standard deviation with all mean values.

\section{Results}

We monitored 121 Bobolink (15 within-year, 106 between-year) and 436 Savannah Sparrow (235 within-year, 201 between-year) pairs. The between-year divorce rates were $84.9 \%$ and $69.1 \%$ for Bobolinks and Savannah Sparrows, respectively. Between years, Bobolinks were more likely to divorce after nest failure $\left(\chi_{1}^{2}=5.63 ; P=0.02\right)$, whereas Savannah Sparrows were not more likely to divorce after nest failure $\left(\chi_{1}^{2}=2.12 ; P=0.15\right)$. Cause of nest failure (depredation vs. haying) did not influence the probability of divorce for Bobolinks $\left(\chi^{2}{ }_{1}=0.28 ; P=0.60\right)$ or Savannah Sparrows $\left(\chi_{1}^{2}=2.02 ; P=0.16\right)$. After controlling for year effects, divorce did not increase reproductive success for Bobolinks $\left(F_{1,104}=0.02 ; P=\right.$ $0.98)$ or Savannah Sparrows $\left(F_{1,199}=1.05 ; P=\right.$ 0.35; Fig. 1).

Between years, female Bobolinks who divorced fledged a significantly greater number of young in their first nest (first nest attempt pre-divorce: 3.71 \pm 1.83 ; second nest attempt post-divorce: $3.11 \pm$ 2.13 ; $t_{92}=2.04, P=0.02$; Fig. 2). Furthermore, female Bobolinks who did not divorce fledged more young in their second nest attempt (first: 1.59 


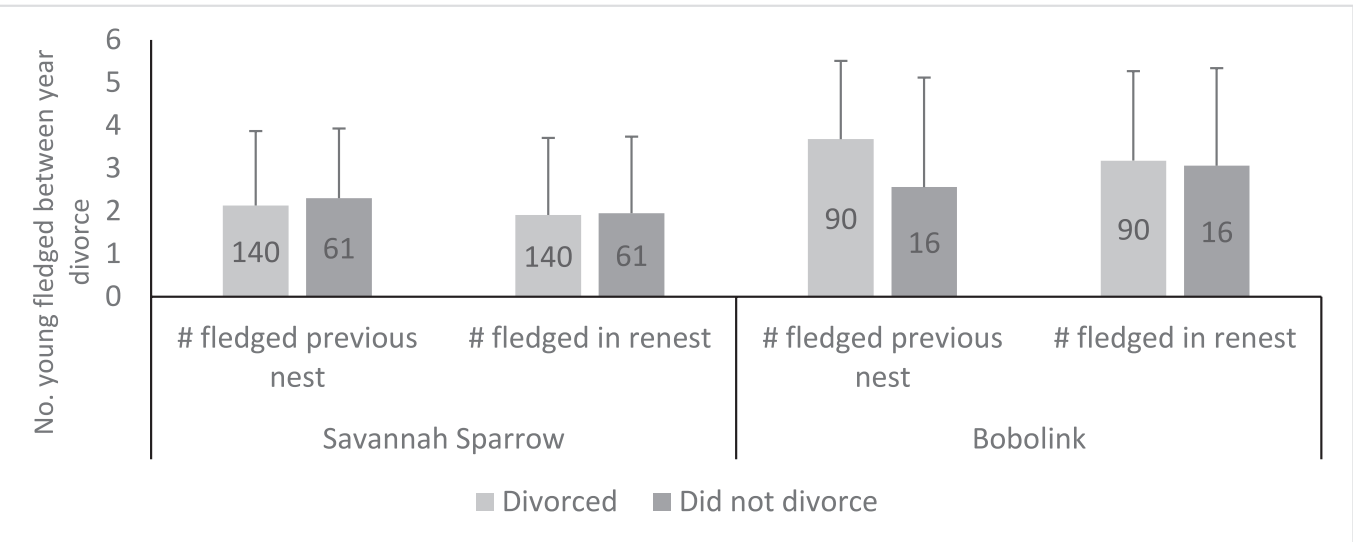

Figure 1. The mean number of young fledged from the first nest and the renest after divorce or re-pairing between years (error bars indicate the standard deviation) in Vermont, USA. Numbers on the bars represent nest sample size.

\pm 2.02 ; second: $2.62 \pm 2.27 ; t_{29}=-1.83, P=$ 0.04). Female Savannah Sparrows who divorced fledged a similar number of young in their first pre-divorce and second post-divorce nests (first: $2.1 \pm 1.77$; second: $1.88 \pm 1.78 ; t_{180}=1.18, P=$ 0.12). Likewise, female Savannah Sparrows who did not divorce fledged a similar number in their first and second nests (first: $1.51 \pm 1.73$; second: $\left.1.62 \pm 1.73 ; t_{256}=-0.71, P=0.24\right)$.

The within-year divorce rates were $0 \%$ and $17 \%$ for Bobolinks and Savannah Sparrows, respectively. Within-year, Savannah Sparrows $\left(\chi^{2}{ }_{1}=6.35 ; P\right.$ $=0.01)$ were more likely to divorce after nest failure. After controlling for year effects, divorce did not increase the number of young fledged for female Bobolinks $\left(F_{1,13}=0.87 ; P=0.44\right)$ or female Savannah Sparrows $\left(F_{1,223}=0.86 ; P=\right.$ 0.43; Fig. 3). Cause of nest failure (depredation vs. haying) did not influence Savannah Sparrows' decision to divorce within a given year $\left(\chi^{2}=1.48\right.$ $P=0.22$; Fig. 4). Our sample was insufficient to test the effects of depredation vs. haying on Bobolinks.

\section{Discussion}

While divorce may be an adaptive strategy for increasing reproductive success in unpredictable

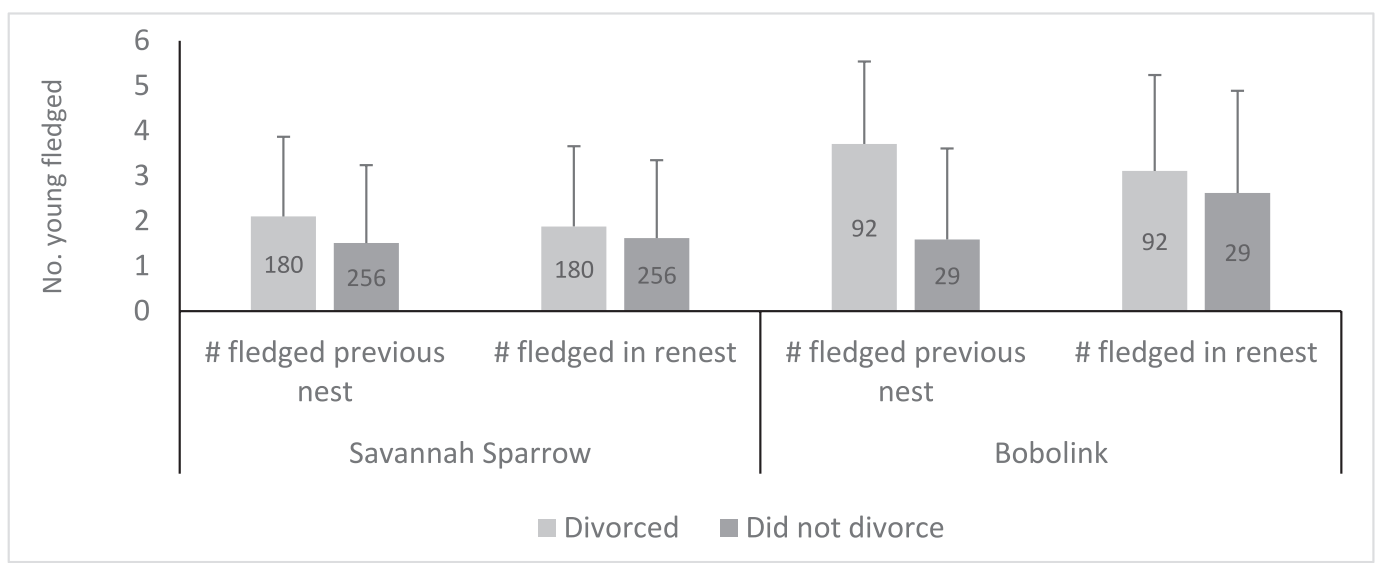

Figure 2. The mean number of young fledged from the first nest and the renest after divorce or re-pairing (error bars indicate the standard deviation) in Vermont, USA. This sample pools both within- and between-year renests. Numbers on the bars represent nest sample size. 


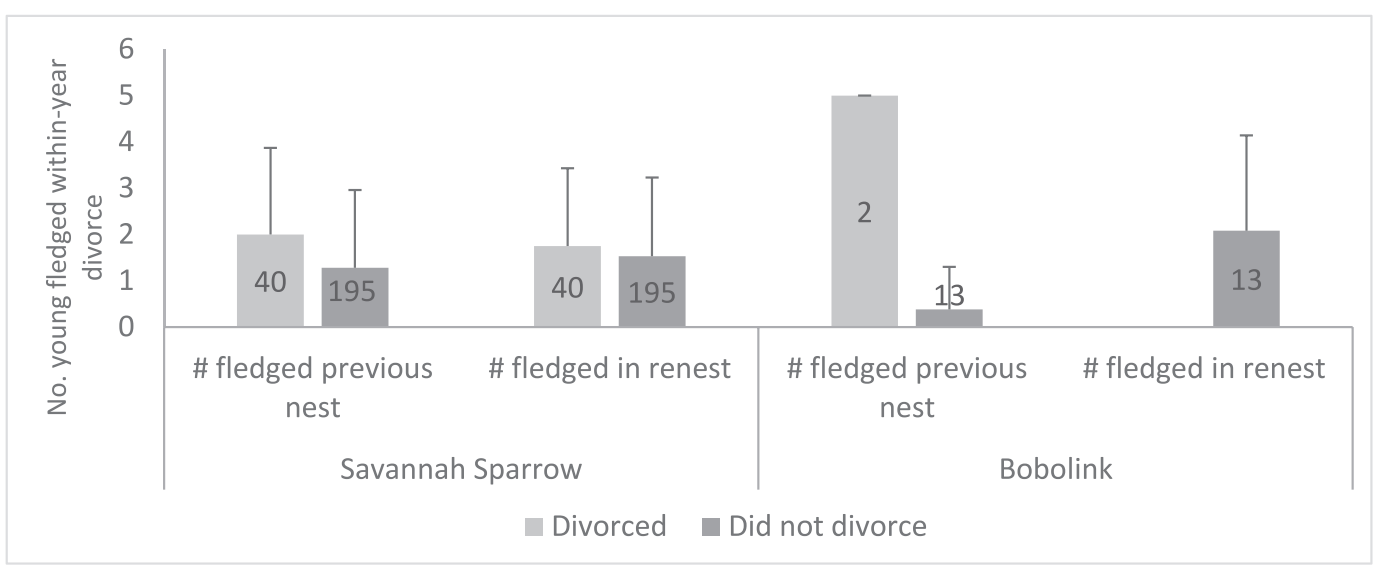

Figure 3. Within-year mean number of young fledged from the first nest and the renest after divorce or re-pairing of Savannah Sparrows in Vermont, USA (error bars indicate the standard deviation). Numbers on bars represent sample size.

environments - as with grassland habitats (Wheelwright and Teplitsky 2017)—we found that divorce rates were not affected by agricultural haying either within-year (Savannah Sparrows) or between-year (Bobolinks and Savannah Sparrows). This result contrasts notably with the one other study of divorce in grassland birds nesting in agricultural grasslands in 3 critical ways. First, with notably higher within-year divorce rates than our study, Grüebler et al. (2015) found that $65 \%$ of pair bonds dissolved post-haying, although $13 \%$ of these dissolved pairings were caused by adult mortality (primarily caused by the machinery). We have never documented direct adult mortality from the haying process. Second, in Grüebler et al.
(2015), only a portion of the habitat within a field - and therefore a portion of the active nestswas subjected to haying, thereby maintaining an asynchronous fertility schedule across all breeding females; by contrast, in our study, when a field was hayed, it was hayed in its entirety, and all nests failed synchronously, thereby artificially causing breeding synchrony of all birds. Third, Grüebler et al. (2015) differentiated between birds that had dispersed and those that did not disperse. In our work, Savannah Sparrows generally remained on the field and renested - none were found to have dispersed within our $3 \mathrm{~km}$ search radius within a given year (Cava et al. 2016); therefore, dispersal distance did not influence divorce rates. Taken

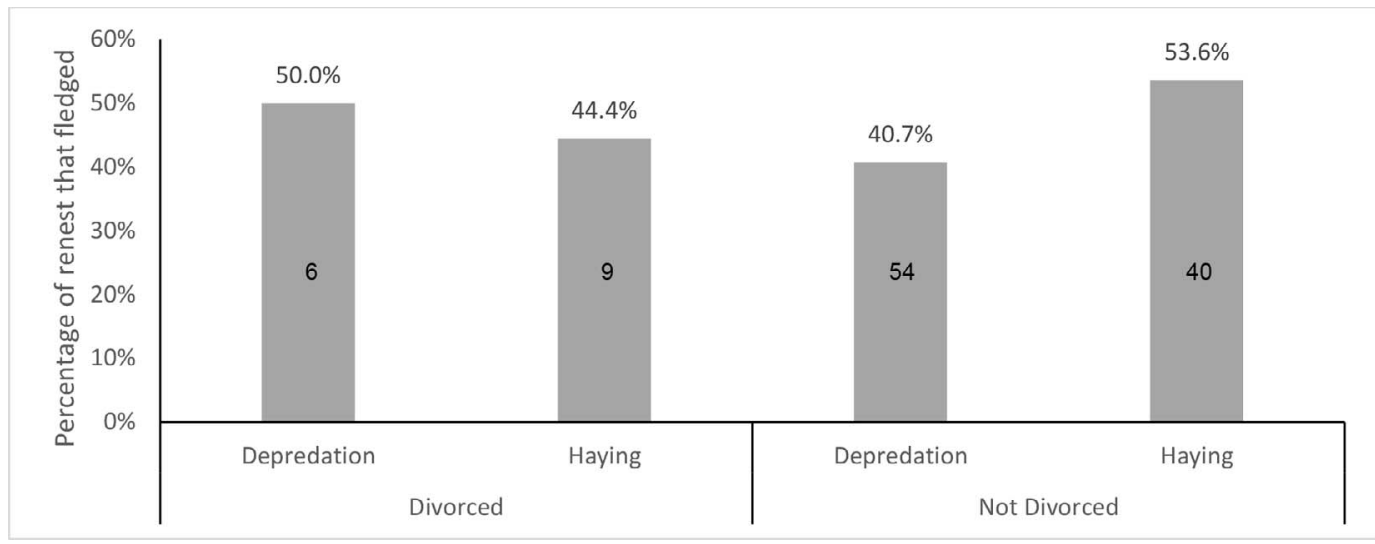

Figure 4. Percentage (and sample size) of Savannah Sparrow nests that fledged young after their first nest failed either from predation or haying in Vermont, USA. 
together, these contrasts suggest that habitat management, including agricultural haying, can have diverse effects on social and resulting reproductive processes in birds.

Our results indicate no benefit and potentially a significant reproductive cost to divorce, and that these effects vary between species. There was no adaptive benefit or cost to divorce for Savannah Sparrows. By contrast, Bobolinks showed a decrease in reproductive success after divorce, and an increase in reproductive success after re-pairing with the same mate between years. There are 3 hypotheses for why birds divorce if there is no adaptive benefit. The "accidental loss" hypothesis suggests divorce is a result of partners losing one another during migration. In our case, we only included pairs within the sample where both the male and female were present and available for pairing. Further, it is unlikely that pairs migrate together in these species as males typically arrive on the breeding grounds before females. The "forced divorce" hypothesis suggests divorce as a result of territory battles in which a member of the pair is expelled from the territory by a conspecific. We did not collect territory defense behavior data that would allow us to test this hypothesis. Third, synchronous arrival of pairs to their breeding grounds is important for maintaining pair relationships (Gunnarsson et al. 2004). Therefore, the "musical chairs" hypothesis suggests that divorce occurs due to delayed arrival of one member of a pair to the breeding ground, resulting in its previous mate finding a new partner or settling on a different territory (Dhondt and Adriaensen 1994, Choudhury 1995). Our data do not support this hypothesis because haying, which synchronized all breeding females (Perlut et al. 2008a), did not affect withinyear divorce rates. However, both delayed arrival and an inability to identify social mates before haying (e.g., birds paired but did not yet have a nest) could influence between-year divorce patterns. While these hypotheses present useful models with which to consider our results, they do not explain the nature of divorce in our study populations.

Additionally, the costs and benefits of divorce may vary between sex, age, and social status (Culina et al. 2015). For example, an island population of Savannah Sparrows had a rate of between-year divorce of $47.0 \%$ (Wheelwright and Teplitsky 2017), similar to, but lower than, what we identified here $(69.1 \%)$. Older females $(\geq 3$ years old) improved fledging success through divorce. In explaining this increased fitness, $47 \%$ of surviving pairs divorced when parental assistance was low by the male or when the male was small-bodied. While we do not have comparable feeding data for which to test these models, given the comparative rate of divorce, we hypothesize that our study population would behave similarly.

For Bobolinks, our results suggest that mate familiarity can increase reproductive success. Other studies showed that fidelity may allow a pair to improve coordination and performance through familiarity (Cooke et al. 1981). For species such as the Bobolink and Savannah Sparrow, staying with the same mate and potentially having the same level of nest success may be preferred over the risk of not finding a new mate.

Between years, cause of nest failure (depredation vs. haying) did not influence the divorce rate of either species. Likewise, within-year divorce for Savannah Sparrows was not influenced by cause of failure. We originally hypothesized that breeding synchrony would influence divorce rates, but this was not the case. Renests on hayed fields were highly synchronous due to failure of nests occurring simultaneously (Perlut et al. 2008a), while depredation occurred asynchronously across the breeding season. There is some evidence that suggests that highly synchronous breeding will reduce females' ability to assess male quality because males may guard females to protect from extra-pair copulations (Westneat et al. 1990), thus making female interactions with more than one male less likely and increasing the probability of re-pairing. This constraint may explain why there was no effect of haying on the probability of divorce.

Our study is one of few that explores the reproductive consequences of both within-year and between-year divorce and may be one of the first that shows a decrease in the number of young fledged after divorce. Future work should identify the mechanisms underlying divorce in birds to better understand not only why these events occur, but also how human habitat modification may specifically impact the frequency or reproductive success resulting from these events.

\section{Acknowledgments}

Special thanks to the summer 2017 field crew and the many field technicians that have helped with data collection over the course of the research. Thanks to Shelburne Farms 
and landowners for allowing access to their beautiful properties. This work was funded by the College of Arts and Sciences SURE program, the Eppley Foundation, Toyota Together Green, and D. Galipeau.

\section{Literature cited}

Beguin N, Leboucher G, Bruckert L, Kreutzer M. 2006. Mate preferences in female canaries (Serinus canaria) within a breeding season. Acta Ethologica. 9:65-70.

Botero CA, Rubenstein DR. 2012. Fluctuating environments, sexual selection and the evolution of flexible mate choice in birds. PLOS One. 7(2):e32311.

Cava JA, Perlut NG, Travis SE. 2016. Why come back home? Investigating the intrinsic and extrinsic proximate factors that influence natal philopatry in migratory passerines. Animal Behaviour. 118:39-46.

Choudhury S. 1995. Divorce in birds: A review of the hypotheses. Animal Behaviour. 50:413-429.

Cooke F, Bousfield M, Sadura A. 1981. Mate change and reproductive success in the Lesser Snow Goose. Condor. 83:322-327.

Crino OL, Buchanan KL, Fanson BG, Hurley LL, Smiley KO, Griffith SC. 2016. Divorce in the socially monogamous Zebra Finch: Hormonal mechanisms and reproductive consequences. Hormones and Behavior. 87:155-163.

Culina A, Radersma R, Sheldon BC. 2015. Trading up: The fitness consequences of divorce in monogamous birds. Biological Review. 90:1015-1034.

Dhondt AA, Adriaensen F. 1994. Causes and effects of divorce in the Blue Tit Parus caeruleus. Journal of Animal Ecology. 63:979-987.

Grüebler MU, Schuler H, Spaar R, Naef-Daenzer B. 2015. Behavioural response to anthropogenic habitat disturbance: Indirect impact of harvesting on Whinchat populations in Switzerland. Biological Conservation. 86:52-59.
Gunnarsson TG, Gill JA, Sigurbjornsson T, Sutherland WJ. 2004. Pair bonds: Arrival synchrony in migratory birds. Nature. 431(7009):646.

Hannah L, Carr JL, Lankerani A. 1995. Human disturbance and natural habitat: A biome level analysis of a global dataset. Biodiversity and Conservation. 4:128e155.

Perlut NG, Freeman-Gallant CR, Strong AM, Donovan TM, Kilpatrick CW, Zalik NJ. 2008a. Agricultural management affects evolutionary processes in a migratory songbird. Molecular Ecology. 17:1248-1255.

Perlut NG, Strong AM, Donovan TM, Buckley NJ. 2006. Grassland songbirds in a dynamic management landscape: Behavioral responses and management strategies. Ecological Applications. 16:2235-2247.

Perlut NG, Strong AM, Donovan TM, Buckley NJ. 2008b. Regional population viability of grassland songbirds: Effects of agricultural management. Biological Conservation. 141:3139-3151.

Renfrew RB, Kim D, Perlut NG, Fox J, Marra PP. 2013. Phenological matching across hemispheres in a longdistance migratory bird. Diversity and Distributions. 19:1008-1019.

Renfrew RB, Strong AM, Perlut NG, Martin SG, Gavin TA. 2015. Bobolink (Dolichonyx oryzivorus). In: Poole A, editor. Birds of North America. Ithaca (NY): Cornell Lab of Ornithology. doi:10.2173/bna.176

Shustack DP. 2004. Bobolink and Savannah Sparrow habitat selection in the Champlain Valley [master's thesis]. Burlington (VT): University of Vermont.

Westneat DF, Sherman PW, Morton ML. 1990. The ecology and evolution of extra-pair copulations in birds. Current Ornithology. 7:331-369.

Wheelwright NT, Rising JD. 2008. Savannah Sparrow (Passerculus sandwichensis). In: Poole A, Gill F, editors. Birds of North America, no. 45. Philadelphia (PA): Academy of Natural Sciences and Washington (DC): American Ornithologists' Union.

Wheelwright NT, Teplitsky C. 2017. Divorce in an island bird population: Causes, consequences, and lack of inheritance. American Naturalist. 190:557-569. 